\title{
Infectious arthritis in patients with rheumatoid arthritis
}

Lourdes Mateo Soria, Joan Miquel Nolla Solé, Antonio Rozadilla Sacanell, José Valverde García, Daniel Roig Escofet

\begin{abstract}
Eleven cases of infectious arthritis occurring in patients with rheumatoid arthritis are reported. Staphylococcus aureus was the causative organism in eight patients. Streptococcus anginosus and Streptococcus agalactiae in one patient each, and Mycobacterium tuberculosis in two patients. The mean duration of symptoms before diagnosis was 16 days in patients with pyogenic arthritis. The diagnosis of joint infection caused by Mycobacterium tuberculosis was especially delayed (57 days). Four patients died; they were found to have a longer time to diagnosis and two of them had multiple joint infection. Although Staphylococcus aureus is the microorganism most often affecting patients with rheumatoid arthritis, infection caused by Mycobacterium tuberculosis must also be considered in such patients.
\end{abstract}

Patients with rheumatoid arthritis (RA) are especially susceptible to bacterial infection, and joint infection is a well recognised complication, often causing death, which might be related to a delay in diagnosis and treatment. ${ }^{1-8}$

In 1958 , Kellgren $e t a l^{9}$ first reported the

Rheumatology Service, Hospital de Bellvitge "Princeps d'Espanya", University of Barcelona, and L'Hospitalet de Llobregat, Barcelona, Spain

L Mateo Soria

J M Nolla Solé

A Rozadilla Sacanell

J Valverde García

D Roig Escofet

Correspondence to:

Dr Lourdes Mateo Soria,

C/Vilardell 44-46 Esc A 52

Department of Medicine,

Rheumatology Service,

08014 Barcelona, Spain.

Accepted for publication

3 May 1991 association of septic and rheumatoid arthritis in 12 patients. Since then, over 400 cases have been reported, ${ }^{2}$ and the occurrence of septic arthritis in patients with RA ranges ${ }^{1}$ from 0.3 to $3 \%$. The mechanisms causing the increased vulnerability to infection reported in patients with RA have not been identified, but skin defects, glucocorticoid treatment, previous articular damage, and primary defect of the immune system have been considered. ${ }^{1810}$ Staphylococcus aureus has been the causative organism in $75 \%$ of reported cases, ${ }^{1-7}$ but streptococci, ${ }^{11} 12$ Gram negative bacilli, ${ }^{13}$ bacteroides species, fungi, and mycobacteria ${ }^{14}$ 15 have also been isolated.
The poor outcome of patients with RA with joint infection has been recognised in most of the reported series, but the death rate and multiple joint infection have declined in recent years. $^{12}$

We report here 11 cases of joint infection in patients with RA observed in our service during the last nine years.

\section{CASE REPORTS}

Between 1981 and 1989, 11 patients with RA whose disease was complicated by infectious arthritis were identified in our rheumatology service. During this time more than 350 patients with RA were treated at our hospital. Patients who had prosthetic joint infection have not been considered in this study.

The table gives details of the 11 patients. Seven patients were women. The ages ranged from 47 to 72 years (mean 60 years) and the duration of RA from 1 to 25 years (mean 14.5 years). Most of the patients had progressive, deforming arthritis and all had erosive changes when studied radiographically. Rheumatoid factor was present in the serum of all but one patient. Seven of the patients had rheumatoid nodules and all were receiving corticosteroids (6-methylprednisolone, $4-6 \mathrm{mg} /$ day) by mouth at the time of the initial joint infection.

Microorganisms were isolated from the synovial fluid in all patients; blood cultures were positive in four patients. The nine patients with bacterial arthritis were treated with penicillin or cloxacillin injected intravenously, whereas those with tuberculous infection received treatment by mouth.

Patients 6 and 8 died of septic shock during the first day of admission to hospital. Patient 1 , after eight weeks of antibiotic treatment, underwent a rapid deterioration and died of multisystem failure. Patient number 9 died of a myocardial infarction the day before she was

Clinical features of 11 patients with rheumatoid arthritis with joint infection*

\begin{tabular}{|c|c|c|c|c|c|c|c|c|c|c|}
\hline $\begin{array}{l}\text { Patient } \\
\text { No }\end{array}$ & $\begin{array}{l}\text { Age } \\
\text { (years) }\end{array}$ & Sex & $R F$ & $\begin{array}{l}\text { Rheumatoid } \\
\text { nodules } \\
\text { present }\end{array}$ & $\begin{array}{l}\text { Duration } \\
\text { of } R A \\
\text { (years) }\end{array}$ & $\begin{array}{l}\text { Disease } \\
\text { stage }\end{array}$ & Steroids ${ }^{\star}$ & Organism & $\begin{array}{l}\text { Joint } \\
\text { affected }\end{array}$ & $\begin{array}{l}\text { Fever } \\
\text { present }\end{array}$ \\
\hline $\begin{array}{r}1 \\
2 \\
3 \\
4 \\
5 \\
6 \\
7 \\
8 \\
9 \\
10 \\
11\end{array}$ & $\begin{array}{l}47 \\
58 \\
47 \\
55 \\
49 \\
62 \\
66 \\
72 \\
69 \\
68 \\
72\end{array}$ & $\begin{array}{l}\mathbf{F} \\
\mathbf{M} \\
\mathbf{F} \\
\mathbf{M} \\
\mathbf{F} \\
\mathbf{F} \\
\mathbf{F} \\
\mathbf{M} \\
\mathbf{F} \\
\mathbf{M} \\
\mathbf{F}\end{array}$ & $\begin{array}{l}+ \\
+ \\
+ \\
+ \\
+ \\
+ \\
+ \\
+ \\
+ \\
+ \\
+\end{array}$ & $\begin{array}{l}\text { Yes } \\
\text { Yes } \\
\text { No } \\
\text { Yes } \\
\text { Yes } \\
\text { Yes } \\
\text { No } \\
\text { Yes } \\
\text { No } \\
\text { Yes } \\
\text { No }\end{array}$ & $\begin{array}{r}15 \\
1 \\
25 \\
2 \\
12 \\
15 \\
23 \\
19 \\
11 \\
17 \\
20\end{array}$ & $\begin{array}{l}\text { IV } \\
\text { II } \\
\text { III } \\
\text { II } \\
\text { III } \\
\text { III } \\
\text { III } \\
\text { III } \\
\text { III } \\
\text { III } \\
\text { III }\end{array}$ & $\begin{array}{l}\text { Yes } \\
\text { Yes } \\
\text { Yes } \\
\text { Yes } \\
\text { Yes } \\
\text { Yes } \\
\text { Yes } \\
\text { Yes } \\
\text { Yes } \\
\text { Yes } \\
\text { Yes }\end{array}$ & $\begin{array}{l}S \text {. anginosius } \\
S \text {. agalactiae } \\
S \text {. aureus } \\
S \text {. aureus } \\
S \text {. aureus } \\
S \text {. aureus } \\
S \text {. aureus } \\
S \text {. aureus } \\
S \text {. aureus } \\
M \text {. tuberculosis } \\
M \text {. tuberculosis }\end{array}$ & $\begin{array}{l}\text { Knee } \\
\text { Knee } \\
\text { Metatarsal } \\
\text { Shoulder } \\
\text { Wrist } \\
\text { Polyarticular } \\
\text { Knee } \\
\text { Polyarticular } \\
\text { Knee } \\
\text { Knee } \\
\text { Knee }\end{array}$ & $\begin{array}{l}\text { Yes } \\
\text { Yes } \\
\text { No } \\
\text { Yes } \\
\text { Yes } \\
\text { Yes } \\
\text { No } \\
\text { No } \\
\text { Yes } \\
\text { No } \\
\text { No }\end{array}$ \\
\hline
\end{tabular}


discharged from hospital, with complete resolution of joint infection.

\section{Discussion}

Patients with longstanding, debilitating RA have a particular susceptibility to acute pyarthrosis. These patients may have a lowered resistance to infection in general, and those who are receiving long term corticosteroid treatment are especially susceptible. ${ }^{1-4}$ The use of corticosteroids and anti-inflammatory drugs in these patients can mask local symptoms in addition to fever, contributing to the delay in diagnosis. ${ }^{1249}$ The clinical features of pyarthrosis, particularly with multiple joint infection, may be impossible to distinguish from those of an exacerbation of RA, resulting in a delay in the appropriate treatment. Pyarthrosis must be suspected in all patients with RA who show a deterioration in their clinical course, and prompt aspiration of the inflamed joints with microscopic examination and culture of the fluid is imperative.

The time elapsed before the start of treatment seems to be an important factor in prognosis. ${ }^{1-4}$ Some workers have noticed that patients who were untreated for one week or more had a much poorer prognosis than those treated promptly. ${ }^{24}$ In our series, the four patients who died were not diagnosed until some time after infection (mean 27.5 days) and two had multiple joint infection. The death rate among patients with RA with joint infection is now considered ${ }^{12}$ to be between 20 and $25 \%$, but in those patients with multiple joint infection ${ }^{2}{ }^{4}$ it may be as high as $55-60 \%$.

The knee is the most commonly affected joint, accounting for $42 \%$ of the infected joints reported. ${ }^{1-4}$ In our patients the knee was affected in $54 \%$, followed by the wrist, ankle, and shoulder. Staphylococcus aureus account for over $75 \%$ of cases of pyarthrosis in patients with RA. ${ }^{1-7}$ The rest are caused by various streptococcal strains, ${ }^{11}{ }^{12}$ Gram negative bacilli, ${ }^{13}$ anaerobes in addition to fungi, and mycobacteria. ${ }^{1{ }^{14}} \mathrm{~A}$ number of cases of atypical mycobacterial septic arthritis, associated especially with Mycobacterium kansasii, have been reported in patients with RA. ${ }^{15}$ In two recent reviews of work published during the past 40 years, ${ }^{12}$ joint infection by Mycobacterium tuberculosis in patients with RA is not mentioned. This might be explained by the low incidence of osteoarticular tuberculosis in developed regions such as North America and Britain. Our two patients with tuberculous arthritis had symptoms for a long time before diagnosis, as is usual in this infection.

The erythrocyte sedimentation rate was increased in all our patients, but it is of no diagnostic value in distinguishing infection from RA activity. Blood cultures were positive in four of 11 patients (36\%), similar to the reported occurrence.

Death as a result of pyarthrosis occurred in three of our patients (27\%), two with multiple joint infection. Surgical joint drainage was performed in five of our patients, all with optimal results. Arthroscopy has been shown to be helpful in joint drainage, ${ }^{12}$ but comparative studies are necessary.

Our experience shows that infection must be considered in all patients with RA who show a deterioration in their clinical course or when activity concentrates in one joint. As in our series, infection caused by Mycobacterium tuberculosis should be considered in countries which still have high rates of tuberculous infection.

1 Goldenberg D L. Infectious arthritis complicating rheumatoid arthritis and other chronic rheumatic disorders. Arthritis Rheum 1989; 32: 496-502.

2 Gardner G C, Weisman M H. Pyarthrosis in patients with rheumatoid arthritis: a report of 13 cases and a review of the literature from the past 40 years. Am $\mathcal{F}$ Med 1990; 88: 503-11.

3 Kraft S M, Panush R S, Longley S. Unrecognized staphylococcal pyarthrosis with rheumatoid arthritis. Semin Arthritis Rheum 1985; 14: 196-201.

4 Rowe I F, Deans A C, Keat A C S. Pyogenic infection and rheumatoid arthritis. Postgrad Med F 1987; 63: 19-22.

5 Rimoin D L, Wennberg J E. Acute septic arthritis complicating chronic rheumatoid arthritis. FAMA 1966; 196: 617-21.

6 Karten I. Septic arthritis complicating rheumatoid arthritis. Ann Intern Med 1969; 70: 1147-58.

7 Myers A R, Miller L M, Pinals R S. Pyarthrosis complicating rheumatoid arthritis. Lancet 1969; ii: 714-6.

8 Van Albada-Kuipers G A, Linthorst J, Peeters E A J, et al. Frequency of infection among patients with rheumatoid arthritis versus patients with osteoarthritis or soft tissue rheumatism. Arthritis Rheum 1988; 31: 667-71.

9 Kellgren J H, Ball J, Fairbrother R W, Barnes $K \mathbf{L}$. Suppurative arthritis complicating rheumatoid arthritis. SMP 1958 ; i: 1193-200.

10 Huskisson E C, Hart F D. Severe, unusual, and recurrent infections in rheumatoid arthritis. Ann Rheum Dis 1972; 31: 118-21.

11 Morley P K, Hull R G, Hall M A. Pneumococcal septic arthritis in rheumatoid arthritis. Ann Rheum Dis 1987; 46: 482-4.

12 Houston B D, Crouch M E, Finch R G. Streptococcus MGintermedius (Streptococcus milleri) septic arthritis in a patient with rheumatoid arthritis. 7 Rheumatol 1980; 7: 89-92.

13 Norden C W, Sellers T F. Hemophilus influenzae pyarthrosis in an adult. FAMA 1964; 189: 694-5.

14 Nolla J M, Rozadilla A, Mateo L, Juanola X. Artritis tuberculosa en pacientes con artritis reumatoide. Rev Esp Reumatol 1990; 17: 117 .

15 Glickstein S L, Nashel D J. Mycobacterium kansasii septic arthritis complicating rheumatic disease: case report and review of the literature. Semin Arthritis Rheum 1987; 16: 231-5.

\begin{tabular}{|c|c|c|c|c|c|c|c|c|}
\hline $\begin{array}{l}\text { Patient } \\
\text { No }\end{array}$ & $\begin{array}{l}\text { Delay in } \\
\text { diagnosis } \\
\text { (days) }\end{array}$ & $\begin{array}{l}\text { Blood } \\
\text { culture }\end{array}$ & $\begin{array}{l}\text { White blood } \\
\text { cell count } \\
\left(10^{9} / l\right)\end{array}$ & $\begin{array}{l}\text { Erythrocyte } \\
\text { sedimentation } \\
\text { rate (mom/h) }\end{array}$ & $\begin{array}{l}\text { Surgical } \\
\text { drainage }\end{array}$ & Complications & Treatment & Outcome \\
\hline $\begin{array}{r}1 \\
2 \\
3 \\
4 \\
5 \\
6 \\
7 \\
8 \\
9 \\
10 \\
11\end{array}$ & $\begin{array}{r}40 \\
2 \\
17 \\
11 \\
2 \\
14 \\
7 \\
24 \\
32 \\
70 \\
45\end{array}$ & $\begin{array}{l}- \\
\overline{-} \\
\overline{-} \\
\overline{+} \\
+ \\
+ \\
+ \\
\overline{-}\end{array}$ & $\begin{array}{r}12640 \\
14300 \\
9500 \\
6500 \\
5900 \\
16600 \\
7700 \\
14300 \\
13000 \\
7500 \\
7000\end{array}$ & $\begin{array}{r}63 \\
130 \\
75 \\
49 \\
53 \\
125 \\
76 \\
78 \\
86 \\
112 \\
60\end{array}$ & $\begin{array}{l}\text { No } \\
\text { No } \\
\text { Yes } \\
\text { No } \\
\text { Yes } \\
\text { No } \\
\text { Yes } \\
\text { No } \\
\text { Yes } \\
\text { Yes } \\
\text { No }\end{array}$ & $\begin{array}{l}\text { Intra-abdominal abscess } \\
\text { No } \\
\text { No } \\
\text { No } \\
\text { No } \\
\text { Septic shock } \\
\text { No } \\
\text { Septic shock } \\
\text { Myocardial infarction } \\
\text { No } \\
\text { Osteomyelitis D10-D11 }\end{array}$ & $\begin{array}{l}\text { Penicillin IV, ciprofloxacin } \\
\text { Penicillin IV } \\
\text { Cloxacillin IV } \\
\text { Cloxacillin IV } \\
\text { Cloxacillin IV } \\
\text { Cloxacillin IV, cefotaxime } \\
\text { Cloxacillin IV } \\
\text { Cloxacillin IV } \\
\text { Cloxacillin IV } \\
\text { Isoniazid + rifampicin + } \\
\text { ethambutol }\end{array}$ & $\begin{array}{l}\text { Died } \\
\text { Recovered } \\
\text { Recovered } \\
\text { Recovered } \\
\text { Recovered } \\
\text { Died } \\
\text { Recovered } \\
\text { Died } \\
\text { Died } \\
\text { Recovered } \\
\text { Recovered }\end{array}$ \\
\hline
\end{tabular}

